\title{
Technology Transfer Spillover from FDI-A Comprehensive Literature Review
}

\author{
Shushu Feng \\ International Business School \\ Yunnan University of Finance and Economics \\ Kunming, China \\ shushufeng@gmail.com
}

\begin{abstract}
Technology can be transferred between countries through different channels such as international trade, foreign investment and contract transfer. The direct impact of foreign investment on business efficiency has made foreign investment create a positive spillover effect for local enterprises and become the most important international tool for enterprise technology transfer. This research reviews recent literature on the conceptualization, measurement and the mechanism of FDI spillover. It also reviews the factors that affecting the technology transfer spillover from FDI. With the industrial transfer, the pace of global processing industry shifting to Southeast Asian countries or regions is accelerating, and the desire of countries in the region to introduce production technology is very urgent. The implications justify the importance of technology transfer spillover as it benefit from competition of foreign firms as the competitive pressure induces domestic firms to use more efficiently their existing technologies, or search for new ones so that they are able to maintain their market shares.
\end{abstract}

Keywords: technology transfer, FDI, spillover effect

\section{INTRODUCTION}

The term technology transfer was first proposed by the United States to spread its space technology to the civilian sector. Its initial meaning refers to the flow and penetration of technology in the technical field or geographical area. In 1964, the first United Nations Conference on Trade Development officially proposed technology transfer as a strategy for solving North-South problems, defining it as system knowledge about the transfer of a certain product, the application of a process, or the provision of a service.

The main channels of technology transfer are licensing trade, technical consulting, technical services and assistance. Technology can be transferred between different countries through various channels such as international trade, foreign investment and contract transfer. International trade transfers new technologies included in commodity goods, such as new differentiated products or capital goods and equipment, while foreign direct investment transfers knowledge and technology between multinational companies or foreign companies and local joint venture partners. A contractual transfer is a transaction that converts technology into intellectual property, such as the way a license is contracted. In addition to the traditional technology transfer model, technology incubator model, technology transfer platform model and technology startup enterprise model, through the refinement of patent technology transfer policies and regulations, establish a multichannel, multi-agent technology transfer model under the policy support system.

\section{The Existence of TechnOlOgy Transfer SpILlover THROUGH FDI}

Foreign direct investment(Thereafter, FDI) is an important source of the company's most important international technology transfer tool and production capacity, as it helps host countries' domestic industries catch up with international technology frontiers (Newman et al, 2015)[1]. Foreign direct investment may also be the cheapest way to transfer technology because recipient companies often do not have to fund new technologies (Iwasaki \& Tokunaga, 2016) [2]. The technology used only by foreign affiliates has a limited impact on the host economy. Only through various forms of spillover or externality can technology be disseminated in the host country (Martin \& Bell, 2005) [3]. When a company's activities lead to technological advances that increase the productivity of another company, technology spillovers occur, and the first company cannot get all the benefits of its technology creation (Sinani \& Meyer, 2002) [4]

There are many literatures on the existence of technology transfer spillover effects of foreign direct investment. The existence of spillover effects is based on two assumptions. The first is that multinational companies have better access to advanced technologies and other advantages, and therefore have higher levels of productivity. The second assumption is that technology-based assets transferred to the host country are characterized by public interest. These assets can be disseminated and used through demonstration effects, worker movements or direct contact with local agents, and transferred from multinational companies to local businesses. Correspondingly, the spillover of technology transfer can be achieved through four main channels: demonstration imitation, competition, employee training and external connectivity (Kokko, 2001) [5]. Not all spillovers are positive, because when foreign companies with technological advantages force domestic firms to exit the market, foreign direct investment 
creates negative externalities. The positive spillover effect of technology transfer occurs when foreign companies show their companies adjust and imitate advanced technologies when training their employees (Kokko, 1996)[6]. The negative spillover effect of technology transfer occurs when foreign companies with advanced technology produce products at lower marginal costs, plundering the original market share of domestic companies, leading to a negative impact of domestic advanced technology to domestic companies, while domestic

productivity decline (Aitken \& Harrison, 1999) [7]. Especially in the short term, competition will have a negative impact on the productivity of local companies. However, domestic companies can also maintain their market share by making more efficient use of existing technologies or investing in new technologies (Blomstrom \& Kokko, 2003). [8]
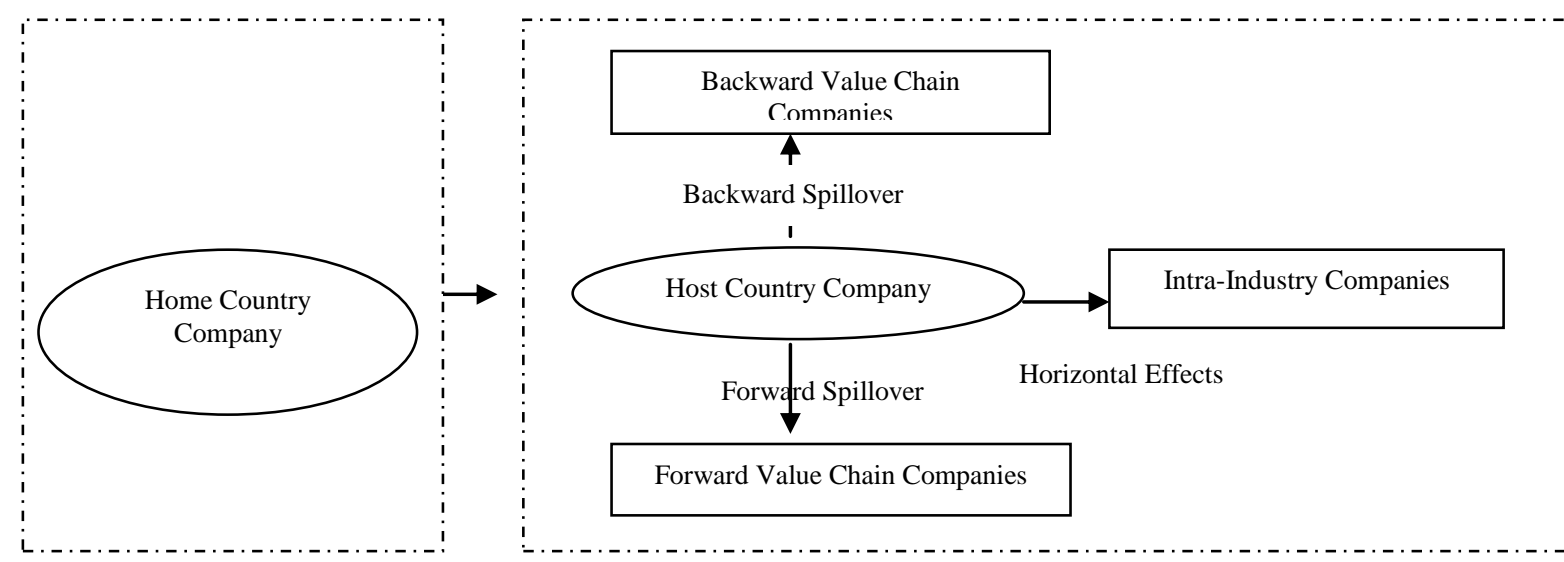

Fig. 1. The mechanism of technology transfer spillover through FDI

\section{THE MECHANISM OF TECHNOLOGY TRANSFER SPILLOVER THROUGH FDI.}

\section{A. Horizontal Spillover}

Horizontal spillover effects, or intra-industry technology spillovers, are spillovers generated by FDI companies transferring the knowledge and technology they use to competing companies in the same sector. When workers move from foreign-funded enterprises to domestic enterprises, there may be a horizontal spillover effect within the department, and bring new knowledge and new technology learned by workers to domestic enterprises. Similarly, domestic companies may also observe and replicate new technologies used by foreign companies in their industries. However, in the industry, foreign companies compete with domestic companies and will try to prevent technology and knowledge from being leaked to domestic competitors. Gorg \& Greenway (2004)[9] analyzed 42 literatures between 1974 and 2002 and found no positive horizontal spillover effects in the study of foreign direct investment spillover effects in developing countries and countries in transition. A large body of empirical literature also fails to find strong evidence of the effect of horizontal spillovers on productivity growth in domestic companies (Barrios et al, 2011) [10].

\section{B. Vertical Spillover}

Vertical spillover effects, or inter-industry spillovers, are spillover effects that are transferred from a foreign intermediate supplier to a domestic producer or from a foreign company to a domestic input supplier through a supply chain. In the large literature research in developing countries, the main direction of research is vertical spillover effect, that is, the vertical spillover effect caused by the backward linkage between isomorphic foreign companies and domestic suppliers is the main source of productivity.
When domestic companies increase productivity due to the presence of foreign companies in the downstream sector, a backward spillover effect occurs. This spillover effect is most likely to occur in a direct backward linkage, when the productivity of domestic firms that provide input to foreigninvested companies increases. Foreign direct investment into the downstream sector may lead to negative spillovers. When there is a direct link between a foreign company and a domestic input supplier, foreign companies may have more bargaining power during contract negotiations, which will result in lower profits and lower production efficiency of domestic companies. Girma\&Wakelin (2007) [11] suggests that the prerequisite for positive spillover effects through backward linkages is that domestically produced suppliers produce varieties that are similar to foreign companies' input requirements. Therefore, if domestic companies try to provide inputs that are not suitable for production, they may have a negative impact on productivity.

Forward spillover effects occur when foreign direct investment in the upstream sector affects the productivity of downstream domestic firms. This spillover effect may be due to direct contact or external factors, and the effect may be positive or negative. If foreign companies or other domestic companies replicate these inputs, the technology may also spill over to domestic companies that are not directly connected to foreign companies. In this way, positive spillovers in the form of externalities are likely to emerge through this channel, albeit with less likelihood.

In empirical research, Blalock \& Gertler (2004) [12] proposed a method for calculating backward linkages and found a positive vertical spillover effect of Indonesia's foreign investment. Subsequently, Blalock \& Gertler (2008) [13] found that the productivity of companies supplying raw materials to Indonesian foreign-invested companies has 
increased. Similarly, Smarzynska (2002) [14] confirms the positive vertical spillover effect of Lithuania's foreign investment. Javorcik (2004) [15] verified positive vertical spillover effects through a backward relationship between domestic suppliers and some foreign-invested customers in Lithuania. Fujimori \& Sato (2014) [16] conducted empirical analysis of industry panel data in the UK, China, and India, respectively, and identified positive inter-industry spillovers.

TABLE I. EXISTENCE OF TECHNOLOGY TRANSFER SPILlOVER

\begin{tabular}{|c|c|c|c|}
\hline \multicolumn{2}{|c|}{ Spillover Effect } & Yes & No \\
\hline \multicolumn{2}{|c|}{ Horizontal Spillover } & & $\begin{array}{l}\text { Gorg \& Greenway } \\
(2004) \\
\text { Blalock\&Gertler(2008) } \\
\text { Damijan et al (2008) } \\
\text { Barrios et al (2011) }\end{array}$ \\
\hline \multirow[b]{2}{*}{$\begin{array}{l}\text { Vertical } \\
\text { Spillover }\end{array}$} & Forward & \multicolumn{2}{|c|}{ No evidence } \\
\hline & Backward & $\begin{array}{l}\text { Smarzynska (2002) } \\
\text { Blalock \& Gertler } \\
\text { (2004) } \\
\text { Javorcik (2004) } \\
\text { Blalock \& Gertler } \\
\text { (2008) } \\
\text { Fujimori \& Sato } \\
\text { (2014) } \\
\text { Carol et al (2015) }\end{array}$ & \\
\hline
\end{tabular}

\section{FACTORS AFFECTING TECHNOLOGY TRANSFER SPILLOVER EFFECTS THROUGH FDI}

The spillover effect of technology transfer through FDI depends on the characteristics of local firms, which shape the absorptive capacity of firms with internalized spillover effects (Farole \& Winkler, 2012) [17]. Absorptive capacity of domestic firms refers to their ability to identify, absorb and utilize external knowledge and technology for commercial purposes. The stronger the ability of local companies to absorb new technologies and processes, the greater the productivity spillover effects are. However, local companies may be limited by their limited absorptive capacity, and the expected productivity spillover effects of foreign direct investment may not appear or even have negative spillover effects. Factors affecting the absorptive capacity of local businesses include (i) the technological gap between foreign and local companies; (ii) the size of local firms; (iii) the export patterns of local firms; and (iv) the proportion of skilled labor at the firm level.

The technological gap between foreign and local companies has been recognized as one of the important regulators of the potential for foreign direct investment spillovers (Kokko et al, 1996) [6]. However, research on the spillover effects of technological gaps on FDI is indeed just. Some believe that the huge technological gap between foreign and local companies will increase positive spillovers because of the large room for improvement (Wang \& Blomstrom, 1992) [18]. Others believe that domestic companies need some minimum basic capacity to benefit from spillovers, so smaller technology bureaus between foreign and local firms can lead to greater spillovers (Blomstrom \&Kokko, 1998) [8]. However, recent studies have also found that productivity spillovers may not be achieved if the technology gap between foreign and local companies is too large or too small (Blalock \& Gerler, 2008) [13]. Kokko (1994) [19] used Mexico's cross-sectional industry-level data to show that the technology spillover effect is small due to the large technological gap between foreign companies and local companies. Kokko et al (1996) [6] extended Kokko's (1994) [19] analysis of Mexico, using Uruguay's cross-sectional company data to study the effects of technological gaps on technology spillovers. The results show that the smaller technology gap between foreign companies and domestic companies has increased technology spillovers. Conversely, Sjoholm (1999) [20] used cross-sectional data from 8086 companies in Indonesia to show that the greater the technological gap between domestic and foreign companies, the greater the spillover effect.

Another factor affecting the extent and nature of FDI spillovers is the size of the company (Sinani \& Meyer, 2004) [4]. Larger local companies often have strong capabilities to compete with foreign companies and have the ability to imitate their skills and management experience, who are able to pay higher wages to attract workers employed by foreign companies. In addition, larger companies may operate at a level that lacks the necessary productivity and knowledge to produce higher spillover benefits from foreign direct investment. Boly et al (2013)[21] using company-level data to study 19 sub-Saharan economies shows that large and young companies have more positive spillover effects than other types of companies. Conversely, according to a sample of 3,742 companies operating in Greece in 1997, Dimelis \& Louri (2004) [22] found that productivity spillovers were most pronounced in small companies. Sinani \& Meyer (2004) [4] also found the same phenomenon in Estonia, especially for small businesses with a high proportion of skilled labor, and the spillover effect of foreign investment is more obvious.

Export behavior is also related to the ability of domestic companies to absorb new technologies and management experience. There are two opposing views in the literature on the role of export behavior in obtaining spillover effects of foreign direct investment. On the one hand, domestic exporters tend to have stronger capabilities to enable them to mitigate the negative spillover effects of foreign direct investment (Crespo \& Fontoura, 2007) [23]. On the other hand local export companies have other additional channels to learn internationally advanced knowledge, skills and technology, so the possibility of externalities triggered by foreign direct investment is limited (Sinani \& Meyer, 2004) [4]. In a large body of empirical research, there is no clear evidence of whether export behavior will enhance or reduce the spillover effects of foreign direct investment. Barrios \& Strobl (2002) [24] studied data on Spanish manufacturing companies between 1990 and 1998, indicating that the growth in foreign direct investment spillovers is greater for exporting firms. Girma et al (2008) [11] also found horizontal spillover effects in the UK. The same is true for Hungary (Schoors \& Van der Tol, 2002) [25]. Other literature has found that local exporters have little or no productivity spillover effects (Sinani \& Meyer, 1994) [4].

The ability of domestic companies to absorb new technologies and management experience is also related to 
their proportion of skilled labor. Investing in skilled labor and R\&D can not only enhance innovation, but also enhance corporate identification, the ability to absorb external knowledge and use it for commercial purposes (Sinani \& Meyer, 2004) [4]. Blalock \& Gertler (2008) [13] used 19881996 Indonesian manufacturing data to conduct research, showing that the proportion of skilled labor has greatly increased the spillover effect of foreign direct investment by domestic enterprises. However, in a highly skilled country like the UK, Girma \& Wakelin (2007) [11] confirmed this conclusion only in small businesses. Sinani \& Meyer (2004) [4] found that a larger proportion of skilled labor has increased the positive spillover effects of large Estonian companies. Cuyvers et al (2008) [26] found that the human capital intensity of a firm does not determine its ability to use foreign technology in Cambodian manufacturing.

Other macro factors, such as the level of economic development of the host country, the degree of external development, institutional factors, the level of financial market development, and the level of industrial development will also affect the spillover effects of foreign direct investment. Countries with high levels of economic development are more likely to attract foreign investment and are more likely to have spillover effects (Fujimori \& Sato, 2015) [16]. When the level of economic development of the host country reaches a certain threshold, the spillover effect will be significant; the greater the spillover effect of foreign direct investment in countries with a strong degree of openness (Krammer, 2010) [27]. This level has a threshold effect, and it can only promote the spillover of foreign direct investment at a moderate level of openness (Guo, 2013)[28]; from the perspective of institutional factors, under the imperfect market system, foreign investors' investment hospitals will Lowering will affect the ability of the host country's learning to imitate, making the spillover effect not obvious (Chen\& Xu, 2014) [29]. The more robust the market system of the host country will increase the cost of local companies to absorb advanced technology and reduce the enthusiasm of absorbing advanced technology, resulting in insignificant spillover effects. The level of financial development (Alfaro et al, 2010) [30] and the level of industrial development will also affect the spillover effects of foreign direct investment.
TABLE II. FACTORS FOR TECHNOLOGY TRANSFER SPILlOVER THROUGH FDI

\begin{tabular}{|c|c|}
\hline Critical Factors & Literature \\
\hline $\begin{array}{l}\text { Technological gap } \\
\text { between foreign and } \\
\text { local companies }\end{array}$ & 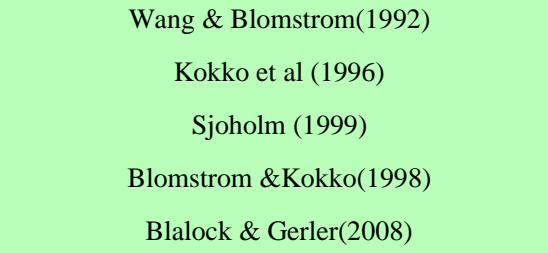 \\
\hline Size of local firms & $\begin{array}{c}\text { Sinani \& Meyer (2004) } \\
\text { Louri (2004) } \\
\text { Boly et al (2013) }\end{array}$ \\
\hline $\begin{array}{l}\text { Export patterns of } \\
\text { local firms }\end{array}$ & $\begin{array}{c}\text { Barrios \& Strobl (2002) } \\
\text { Schoors \& Van der Tol (2002) } \\
\text { Sinani \& Meyer (2004) } \\
\text { Crespo \& Fontoura (2007) } \\
\text { Girma et al (2008) }\end{array}$ \\
\hline $\begin{array}{l}\text { Proportion of skilled } \\
\text { labor at the firm level }\end{array}$ & $\begin{array}{c}\text { Sinani \& Meyer (2004) } \\
\text { Girma \& Wakelin (2007) } \\
\text { Blalock \& Gertler (2008) } \\
\text { Cuyvers et al (2008) }\end{array}$ \\
\hline Other factors & $\begin{array}{l}\text { Economic Development: Fujimori\&Sato (2015) } \\
\text { Degree of Openness: } \quad \text { Krammer (2010) } \\
\qquad \text { Guo (2013) } \\
\text { Institutional Factors: } \quad \text { Chen \& Xu(2013) } \\
\text { Industrial Development: } \quad \text { Alfaro et al, 2010) }\end{array}$ \\
\hline
\end{tabular}

\section{CONCLUSION}

The expected spillover effect of FDI has prompted governments in many economies to adopt policies designed to attract investors. These countries must modernize their industrial structures, upgrade their infrastructure and acquire new capabilities to prosper the market economy. It is widely recognized that FDI plays an important role in this process of restructuring the formerly centrally planned economies by providing a vital source of investment for overcoming the situation of a collapsing state sector and a slowly growing private sector, and by contributing managerial skills, new technology, capital and competition.

First of all, scholars have attempted to show the positive or negative effects of FDI spillover, however, the results are mixed and still remains at an early stage. Therefore, there is still considerable space for researchers to explore technology transfer spillover through FDI especially from developing countries to developing countries. 
Secondly, further research is needed to examine the vertical, which is inter-industry spillover effects as most of the researches are back in 2000s.

Finally, most of the paper focus on developed countries' or transit economies' technology transfer to developing countries. Fewer researches focus on developing countries' technology spillover effects on developing countries. Therefore, more work could be done in this circumstance.

\section{ACKNOWLEDGMENT}

Funding for this research was provided by Yunnan Provincial Department of Education under grants 2019J0952. Special thanks to my PhD supervisor Dr. Liu Ersi, who give his insights on the topic selection of this paper and provide guidance through the review process. And also thanks to the reviewers who provide constructive feedbacks to this paper.

\section{REFERENCES}

[1] Newman, C., Rand, J., Talbot, T., \& Tarp, F., "Technology transfers, foreign investment and productivity spillovers", European Economic Review, 76, 168-187, 2015.

[2] Iwasaki, I., \& Tokunaga, M., "Technology transfer and spillovers from FDI in transition economies: A meta-analysis", Journal of Comparative Economics, 44(4), 1086-1114, 2016

[3] Marin, A., \& Bell, M., "Technology Spillovers from Foreign Direct Investment: An Exploration of the Active Role of MNC Subsidiaries in the Case of Argentina in the 1990s", Journal of Development Studies, 2005.

[4] Sinani, E., \& Meyer, K. E., "Spillovers of technology transfer from FDI: the case of Estonia", Journal of comparative economics, 32(3), 445-466, 2004.

[5] Kokko, A., Zejan, M., \& Tansini, R., "Trade regimes and spillover effects of FDI: Evidence from Uruguay", Weltwirtschaftliches Archiv, 137(1), 124-149, 2001.

[6] Kokko, A., Tansini, R., \& Zejan, M. C., "Local technological capability and productivity spillovers from FDI in the Uruguayan manufacturing sector", The Journal of Development Studies, 32(4), 602-611, 1996.

[7] Aitken, B. J., \& Harrison, A. E., "Do domestic firms benefit from direct foreign investment? Evidence from Venezuela", American economic review, 89(3), 605-618,1999.

[8] Blomström, M., Kokko, A., \& Mucchielli, J. L., "The economics of foreign direct investment incentives. In Foreign direct investment in the real and financial sector of industrial countries", (pp. 37-60). Springer, Berlin, Heidelberg, 2003.

[9] Görg, H., \& Greenaway, D., "Much ado about nothing? Do domestic firms really benefit from foreign direct investment?", The World Bank Research Observer, 19(2), 171-197,2004.

[10] Barrios, S., Görg, H., \& Strobl, E., "Spillovers through backward linkages from multinationals: Measurement matters!", European Economic Review, 55(6), 862-875,2011.

[11] Girma, S., \& Wakelin, K., "Local productivity spillovers from foreign direct investment in the UK electronics industry", Regional Science and Urban Economics, 37(3), 399-412, 2007.

[12] Blalock, G., \& Gertler, P. J., "Firm capabilities and technology adoption: Evidence from foreign direct investment in Indonesia", Unpublished Paper, 2004

[13] Blalock, G., \& Gertler, P. J., "Welfare gains from foreign direct investment through technology transfer to local suppliers", Journal of international Economics, 74(2), 402-421, 2008.
[14] Smarzynska, B., "The composition of foreign direct investment and protection of intellectual property rights: Evidence from transition economies", The World Bank,2002.

[15] Javorcik, B. S., Saggi, K., \& Spatareanu, M., "Does it matter where you come from? Vertical spillovers from foreign direct investment and the nationality of investors", Vertical Spillovers from Foreign Direct Investment and the Nationality of Investors (November 5, 2004). World Bank Policy Research Working Paper, (3449), 2004.

[16] Fujimori, A., \& Sato, T., "Productivity and technology diffusion in India: The spillover effects from foreign direct investment", Journal of Policy Modeling, 37(4), 630-651,2015.

[17] Farole, T., \& Winkler, D., "Foreign firm characteristics, absorptive capacity and the institutional framework: the role of mediating factor for FDI spillovers in low-and middle-income countries", The World Bank, 2012.

[18] Wang, J. Y., \& Blomström, M., "Foreign investment and technology transfer: A simple model", European economic review, 36(1), 137-155, 1992.

[19] Kokko, A., "Technology, market characteristics, and spillovers", Journal of development economics, 43(2), 279-293, 1994.

[20] Sjöholm, F., "Technology gap, competition and spillovers from direct foreign investment: evidence from establishment data", The Journal of Development Studies, 36(1), 53-73,1999

[21] Boly, Amadou, Nicola D. Coniglio, Francesco Prota, and Adnan Seric "Which domestic firms benefit from FDI? Evidence from selected African countries." Development Policy Review 33, no. 5: 615-636, 2015.

[22] Dimelis, S., \& Louri, H., "Foreign direct investment and technology spillovers: Which firms really benefit?", Review of World Economics, 140(2), 230-253,2004.

[23] Crespo, N., \& Fontoura, M. P., "Determinant factors of FDI spilloverswhat do we really know?", World development, 35(3), 410-425,2007.

[24] Barrios, S., Görg, H., \& Strobl, E., "Spillovers through backward linkages from multinationals: Measurement matters!", European Economic Review, 55(6), 862-875,2011.

[25] Schoors, K., \& Van Der Tol, B., "Foreign direct investment spillovers within and between sectors: Evidence from Hungarian data", Working Papers of Faculty of Economics and Business Administration, Ghent University, Belgium, 2002/157, 2002.

[26] Cuyvers, L., Soeng, R., Plasmans, J., \& Van den Bulcke, D., "Productivity spillovers from Foreign Direct Investment in the Cambodian manufacturing sector: evidence from establishment-level data" University of Antwerp, Faculty of Business and Economics, 2008.

[27] Krammer, S. M., "International R\&D spillovers in emerging markets: The impact of trade and foreign direct investment", The Journal of International Trade \& Economic Development, 19(4), 591-623, 2010.

[28] Guo, Qingran, "Regional Differences and Absorptive Capabilities of FDI Technology Spillover Effect_-Based on Threshold Panel Data Model”, Industrial Technology Economy, 2013(8):33-43, 2013.

[29] Chen, Fenglong\&Xu, Kangnin., "Does economic transformation promote FDI technology spillovers: evidence from 23 countries?", World Economy, 2014(3):104-128,2014.

[30] Alfaro, L., Chanda, A., Kalemli-Ozcan, S., \& Sayek, S., "Does foreign direct investment promote growth? Exploring the role of financial markets on linkages", Journal of Development Economics, 91(2), 242 256,2010 